\title{
Cancer of the Ear in Albinism
}

\section{Wilson IB Onuigbo*}

Departments of Pathology and Surgery, Nigeria

Submission: August 08, 2018; Published: September 21, 2018

"Correspondence Address: Wilson IB Onuigbo, Departments of Pathology and Surgery, Founder/Director, Medical Foundation \& Clinic, 8 Nsukka Lane, P. O. Box 1792, Enugu 400001, Nigeria, Email: wilson.onuigbo@gmail.com

\section{Abstract}

Albinism is characterized by impaired melanin biosynthesis which predisposes to carcinoma. The head is taken as the commonest site of its occurrence. Therefore, the question arises as to the ear that borders it. The answer was obtained by studying this organ among the sun beaten Ibo albinos, who are domiciled in South Eastern Nigeria. Surprisingly, contrary to the pessimistic view that albinos seldom live beyond 30 years, two Ibo elements achieved 70 years. This is open to research.

Keywords: Skin; Ear; Albinism; Cancer; Types; Age; Ibos; Nigeria

Abbreviations: Squ: Squamous Cell Carcinoma; Bas: Basoquamous Carcinoma; Und: Undifferentiated carcinoma; Ade: Adenocystic Carcinoma

\section{Introduction}

It was well stated by a South African group that albinism is characterized by impaired melanoma biosynthesis, which is associated with sunlight induced skin cancer [1]. An important aspect is the common involvement of the head and neck as reported from both Nigeria [2] and Tanzania [3]. This leads to the interesting question as to the involvement of the nearby ears. This is answered here by examining the incidence of it among the Ibo ethnic group which is domiciled in the South Eastern Nigeria [4].

\section{Results}

Table 1: Epidemiological data on albino ear cancer.

\begin{tabular}{|c|c|c|c|c|c|c|}
\hline No & Initials & Age & Sex & Side & Doctor & *Diagnosis \\
\hline 1 & IM & 25 & M & $\mathrm{R}$ & Nwozo & Squ \\
\hline 2 & 00 & 30 & M & $\mathrm{R}$ & Echezona & Squ \\
\hline 3 & OC & 30 & M & $\mathrm{R}$ & Echezona & Squ \\
\hline 4 & OS & 54 & M & $\mathrm{R}$ & Nwozo & Squ \\
\hline 5 & NP & 17 & $\mathrm{~F}$ & $\mathrm{~L}$ & Uchendu & Squ \\
\hline 6 & IK & 38 & $\mathrm{~F}$ & $\mathrm{R}$ & Echezona & Ade \\
\hline 7 & OC & 40 & M & $\mathrm{L}$ & Okeke & Und \\
\hline 8 & $\mathrm{AC}$ & 16 & $\mathrm{~F}$ & $\mathrm{R}$ & Echezona & Squ \\
\hline 9 & $\mathrm{AB}$ & 47 & M & $\mathrm{R}$ & Achebe & Squ \\
\hline 10 & EO & 32 & M & $\mathrm{R}$ & Nwozo & Bas \\
\hline 11 & $\mathrm{OM}$ & 60 & M & $\mathrm{L}$ & Ojukwu & Ade \\
\hline 12 & $\mathrm{OA}$ & 70 & M & $\mathrm{R}$ & Nnabuko & Und \\
\hline 13 & $\mathrm{EE}$ & 60 & M & $\mathrm{R}$ & Nnabuko & Bas \\
\hline 14 & EL & 23 & $\mathrm{~F}$ & $\mathrm{~L}$ & Uchendu & Squ \\
\hline
\end{tabular}




\section{Cancer Therapy \& Oncology International Journal}

\begin{tabular}{|l|l|l|l|l|l|c|}
\hline 15 & OE & 70 & F & R & Ogbonnaya & Squ \\
\hline 16 & CB & 20 & F & R & Onah & Und \\
\hline 16 & UO & 26 & F & L & Uchendu & Squ \\
\hline 18 & EO & 40 & M & L & Uchendu & Bas \\
\hline
\end{tabular}

The points of interest are the initials of the names; these are followed by the age, sex, side involved, name of doctor, and the microscopical diagnosis, the list being abbreviated (Table 1).

\section{Discussion}

A single report from Oman concerned "a case of squamous cell carcinoma of external auditory canal" in an albino [6]. The ear was also mentioned in India [7], in Blantyre [8] and in New York [9]. From Tanzania [3], 75\% of the cases were squamous celled. Incidentally, the proportions varied in different Nigerian cohorts, including being "equal" [10], or "low" [11]. In the present study, squamous celled growths and the basal celled growths were in the ratio of 10:3. Moreover, what is not usually mentioned is the adenocystic carcinoma; it occurred twice. Elsewhere, it had already been discussed regarding the face [10]. Furthermore, it has also been discussed at some length as a "molecular variant of albino skin cancer" [12].

The ratio of squamous cell carcinoma to basal cell carcinoma was the close 1.2:1 [13]. In the collected English literature reported from Japan [14], the ratio was more at 3:1. In this community, the ratio was about the same. Concerning age, there is the pessimistic view that albinos "seldom lived more than 30 years" [2]. In Tanzania [3], the median age was 30 years. Hence, the existence of two Ibos aged 70 years is worthy of some research. Sex is worth considering. The male to female ratio was 1.5:1 in Tanzania [3] and 1:1 in another report [13]. The Nigerian ratio was 13 males to 6 females [10]. Here, it is 11 males to 7 females. In considering the doctors, there is a good number of them. The list is led by Dr Uchendu. None of them is a foreigner.

\section{References}

1. Lekalakala PT, Khammissa RAG, Kramer B, OA Ayo-Yusuf, J Lemmer, et al. (2015) Oculocutaneous albinism and squamous cell carcinoma

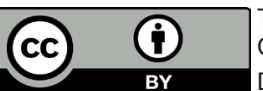

This work is licensed under Creative Commons Attribution 4.0 License

DOI: 10.19080/CTOIJ.2018.12.555828 of the skin of the head and neck in Sub-Sahara Africa. J Skin Cancer 167847: 6 .

2. Yakubu A, Mabogunje OA (1993) Skin cancer in African albinos. Acta Oncol 32(6): 621-622.

3. Mabula JB, Chalya PL, Mchembe MD, Jaka H, Giiti G, et al. (2012) Skin cancers among albinos at a University teaching hospital in Northwestern Tanzania: A retrospective review of 64 cases. BMC Dermatol 12: 5 .

4. Basden GT (1966) Niger Ibos. Cass, London, UK.

5. Macartney JC, Rollaston TP, Codling BW (1980) Use of a histopathology data pool for epidemiological analysis. J Clin Pathol 33(4): 351-353.

6. Furrukh M, Mufti T, Hamid RS, Qureshi A (2014) Squamous cell carcinoma of external auditory canal lacking epidermal growth factor receptor protein overexpression, in an elderly Omani with occulocutaneous albinism treated with palliative radiotherapy. BMJ Case Rep pii: bcr2013203226.

7. Bhargava S, Kumar U, Rokde R (2018) Premalignant and malignant changes of skin in a patient with oculocutaneous albinism: Multiple actinic keratosis and squamous cell carcinoma. Int J Sci Rep 4(2): 4043.

8. Mapurisa G, Masamba L (2010) Locally advanced skin cancer in an albino, treated dilemma. Malawi Med J 22(4): 122-123.

9. Berger E, Hunt R, Tzu J, Patel R, Sanchez M, et al. (2011) Squamous-cell carcinoma in situ in a patient with oculocutaneous albinism. Dermatol Online J 17(10): 22.

10. Ademola SA (2015) An analysis of skin cancer in albinos in Ibadan. Nig J Plast Surg 11(1): 23-28.

11. Onuigbo WIB, Nnabuko RE (2009) Three different carcinomas clustered in one facial focus in albino. Nig J Surg Scis 19: 38-40.

12. Onuigbo WIB (2016) Adenocystic carcinoma as a molecular variant of albino skin cancer. J Med Diag Meth 5: 1.

13. Kiprono SK, Chaula BM, Beltraminelli H (2014) Histological review of skin cancers in African albinos: A 10-year retrospective review. BMC Cancer 14: 157.

\section{Your next submission with Juniper Publishers will reach you the below assets}

- Quality Editorial service

- Swift Peer Review

- Reprints availability

- E-prints Service

- Manuscript Podcast for convenient understanding

- Global attainment for your research

- Manuscript accessibility in different formats ( Pdf, E-pub, Full Text, Audio)

- Unceasing customer service

Track the below URL for one-step submission https://juniperpublishers.com/online-submission.php 